\title{
Astyanax fasciatus AS BIOINDICATOR OF WATER POLLUTION OF RIO DOS SINOS, RS, BRAZIL
}

\author{
SCHULZ, U. H. and MARTINS-JUNIOR, H. \\ Universidade do Vale do Rio dos Sinos, Unisinos, Centro de Ciências da Saúde, Laboratório de \\ Ecologia de Peixes, C.P. 275, CEP 93022-000, São Leopoldo, RS, Brazil \\ Correspondence to: Uwe H. Schulz, Universidade do Vale do Rio dos Sinos, Unisinos, Centro de Ciências da \\ Saúde, Laboratório de Ecologia de Peixes, C.P. 275, CEP 93022-000, São Leopoldo, RS, Brazil, \\ e-mail: uwe@cirrus.unisinos.br \\ Received September 11, 2000 - Accepted November 27, 2000 - Distributed November 30, 2001
}

(With 1 figure)

\begin{abstract}
The effects of an increasing downriver pollution gradient on the reproductive system of Astyanax fasciatus were investigated in the Rio dos Sinos, RS. The comparison of mean oocyte diameters, gonadal indices and gonado-somatic relationships of specimens captured in polluted areas with individuals from unpolluted reference sites revealed a significant decrease of these parameters with increasing water pollution. High loads of organic and industrial sewage are considered responsible for these effects. Condition factors showed an inverse relationship, and increased significantly in downriver polluted areas. The declining gonadal indices showed that energy was allocated to somatic growth. The results of the study recommend the use of A. fasciatus in biomonitoring essays.
\end{abstract}

Key words: Astyanax fasciatus, biomonitoring, heavy metals, reproduction.

\section{RESUMO}

\section{Astyanax fasciatus como bioindicador da poluição da água do Rio dos Sinos, RS, Brasil}

Os efeitos da crescente poluição ao longo do rio sobre o sistema reprodutivo de Astyanax fasciatus foram investigados no Rio dos Sinos, RS. A comparação dos diâmetros médios de ovócitos, do índice gonadal e da relação gônado-somática de espécimes capturadas em áreas poluídas com os indivíduos de locais sem poluição (área de referência) revelou diminuição significativa desses parâmetros com a crescente poluição da água. As cargas elevadas dos esgotos orgânicos e industriais são consideradas responsáveis por esses efeitos. Os fatores de condição mostraram relacionamento inverso e aumentaram significativamente nas áreas poluídas ao longo do rio. A diminuição dos índices gonadais mostrou que a energia é alocada no crescimento somático. Os resultados do estudo recomendam o uso de $A$. fasciatus em experiências de biomonitoramento.

Palavras-chave: Astyanax fasciatus, biomonitoramento, metais pesados, reprodução.

\section{INTRODUCTION}

Antropogenic activities have caused profound alterations in physical and chemical characteristics of the aquatic environment. Industrial and municipal sewage containing heavy metals, hydrocarbons, and halogenated hydrocarbons accumulate in aquatic food webs causing chronic or acute effects in fish populations (Herrick, 1991). The reduced fitness and growth of fish occurs at sublethal levels depending on exposure time, toxicity, and concentrations of the chemical substances involved (Lanno \& Dixon, 1994). The early life stages of fish, like eggs and larvae are particularly sensitive to contaminants (Fiuman, 1993).

Leatherland (1993) examined the evidence for endocrine, reproductive, and developmental dysfunctional states in Great Lakes fish caused by heavy 
metals and halogenated hydrocarbons. These dysfunctions include thyroid lesions, low egg thyroid hormone content, high prevalence of precocious sexual maturation of males, poor expression of secondary sexual characteristics, low concentration of gonadal steroid hormones in females and in males, low egg fertility rates, and high embryo mortality, often associated with embryo deformity (scoliosis, lordosis, conjoined twins, polycephaly, clubbed tail, missing eye and jaw deformities). These pathologic alterations are thought to have contributed to the decline of Great Lake salmonids, particularly Canadian lake trout (Salvelinus namaycush).

Von Westernhagen's review (1988) cites numerous studies which show that exposure of mature female fish to contaminants may reduce ovary weight and egg size, and increase teratological and pathological effects on larvae. Early life stage mortality and decreasing reproductive success are of special importance because their occurrence is not easily detected and alterations in population structures and abundance may only be perceived over the long term.

Biological indicators have been used on many occasions to monitor water quality. Ghetti \& Ravera (1994) mentioned more than 90 different methods based on physiological, pathological, and structural alterations on the community levels. Fish are considered valuable bioindicators on organismic, population, and community level (Karr, 1981; Wootton, 1990). The US National Research Council (1986) recommends the use of bioindicators because "only biological monitoring can tell us what (toxic) materials are doing to organisms".

Studies by the Environmental Protection Agency (Fundação Estadual de Proteção Ambiental - FEPAM) in Brazil's southernmost state, Rio Grande do Sul, revealed high loads of domestic and industrial sewage in the lower reaches of the Rio dos Sinos (FEPAM, 1999). Heavy metals from leather and metallurgical industries particular concern cause. Since no historical data on fish diversity and abundance are available, a comparison of present and past situations is not possible. However, strong anecdotal evidence exists from fishermen who indicate that fish abundance has declined drastically, since the 1970's, with increased industrial activities.
Astyanax fasciatus was chosen as an indicator species to monitor the influence of water quality on the reproductive potential of fish. A. fasciatus is a nonmigratory fish species (Vazzoler, 1992), abundant from Central America to the Río de la Plata delta in Argentina (Nomura, 1984). The species has a central role in riverine food webs (Agostinho et al., 1984). Araújo (1998) and Menni et al. (1996) classified A. fasciatus as relatively tolerant to environmental degradation. These characteristics are needed in an indicator species as recommended by Landres et al. (1988).

The goal of this study is to investigate the influence of water quality on the reproductive potential of mature female A. fasciatus, by comparing oocyte diameter, gonadal index, gonadosomatic relationship, and condition factors along a pollution gradient in the Rio dos Sinos, and to test its aptitude as a bioindicator organism.

\section{MATERIAL AND METHODS}

\section{Description of the study area and study sites}

The Rio dos Sinos is $190 \mathrm{~km}$ long. It originates in the municipal district of Caraá, at an altitude of $740 \mathrm{~m}$ and flows into Lake Guaíba, near the city of Porto Alegre (Fig. 1). Its watershed of $4,002 \mathrm{~km}^{2}$ corresponds to approximately $4.5 \%$ of the Guaíba watershed and $1.5 \%$ of the total area of Rio Grande do Sul State. A total of approximately 1.2 million inhabitants in 29 municipal districts depend on the Rio dos Sinos for their water supply.

The study was carried out in the potamous reaches of Rio dos Sinos. Three sample sites were chosen in the upper (Monjolo), middle (Parobé) and lower (São Leopoldo) potamous portions, following the increasing pollution gradient of the river. Monjolo, the uppermost site, was defined as a reference station. According to FEPAM (1999), water quality at this point was classified from two (on a scale from one, indicating pristine conditions, to four, indicating heavily polluted), with relatively little influence from domestic sewage (Table 1). Industrial effluents are absent in this area. The second site, Parobé, was classified as 3. Agricultural activities are intense, and pesticides were detected (FEPAM, 1999). 


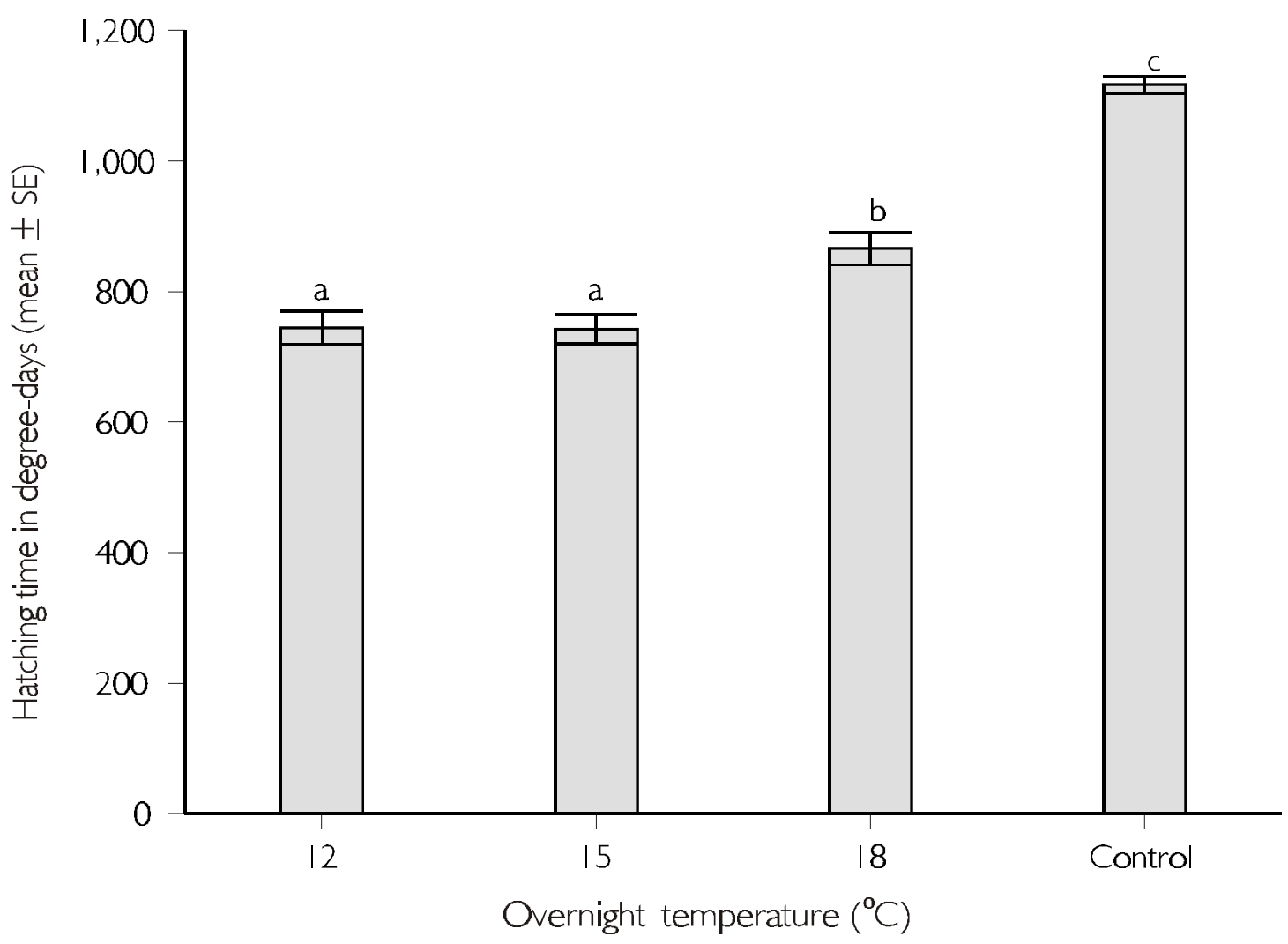

Fig. 1 - Study sites on the Rio dos Sinos $(\downarrow)$.

The river receives an unknown quantity of sewage from a leaching garbage deposit and smaller amounts of industrial effluents. The most polluted collection site was São Leopoldo with water quality of class four. Municipal sewage from the cities of São Leopoldo (180,000 inhabitants, with approximately $20 \%$ of its sewage treated) and Novo Hamburgo (with 225,000 inhabitants, and no sewage treatment) can cause severe oxygen depletion (Table 1). Low $\mathrm{pH}$ values and high concentrations of heavy metals are characteristic of metallurgic and leather industry effluents.

\section{Sampling}

Collections were conducted four times at each site (seasonally) from November 1998 to December 1999. Fish were captured with gill nets of 15 to $25 \mathrm{~mm}$ knot to knot mesh size.
Fifty minutes of electric fishing by boat was also conducted along the river banks, using the aluminum hull of the boat as cathode (at $750 \mathrm{~V}$, max. 4 A, direct current; EFKO, Leutkirch, Germany). Captured individuals were preserved on ice until processing in the laboratory.

Only individuals larger than $10 \mathrm{~cm}$ were examined for: total length $( \pm 1 \mathrm{~mm})$, total weight ( \pm $0.1 \mathrm{~g}$ ), gender (males were not evaluated), and maturity stage of the ovaries [according to criteria established by Nomura (1975) and Vazzoler (1996). Only stage three $=$ mature, were evaluated for: ovary weight $( \pm 0.0001 \mathrm{~g})$, and diameter of 20 oocytes per ovary $( \pm 0.001 \mathrm{~mm})$ and analyzed using graded oculars (ocular micrometer) on a dissecting microscope at $40 \mathrm{x}$ magnification, always obtaining the smallest possible diameter of the cell. 
TABLE 1

Physical-chemical parameters of the investigated sites (FEPAM, 1999).

\begin{tabular}{|c|c|c|c|c|c|}
\hline & & & \multicolumn{3}{|c|}{ Sites } \\
\hline & & & Monjolo (reference) & Parobé & São Leopoldo \\
\hline Diss. $\mathrm{O}_{2}$ & $\mathrm{mg} / \mathrm{L}$ & $\min$. & 6.6 & 4.9 & 0.2 \\
\hline $\mathrm{pH}$ & & $\min$. & 6 & 6.2 & 5.2 \\
\hline $\mathrm{pH}$ & & $\max$. & 8.2 & 7.8 & 7.6 \\
\hline BOD & $\mathrm{mg} / \mathrm{L}$ & $\max$. & 2.7 & 3.6 & 84 \\
\hline Turbidity & NTU & $\max$. & 67 & 135 & 277 \\
\hline TDS & $\mathrm{mg} / \mathrm{L}$ & $\max$. & 250 & 230.2 & 1,090 \\
\hline $\mathrm{Cd}$ & $\mathrm{mg} / \mathrm{L}$ & $\max$. & 0.003 & 0.003 & 0.040 \\
\hline $\mathrm{Pb}$ & $\mathrm{mg} / \mathrm{L}$ & $\max$ & 0.025 & 0.025 & 0.110 \\
\hline $\mathrm{Cu}$ & $\mathrm{mg} / \mathrm{L}$ & $\max$. & 0.014 & 0.002 & 0.034 \\
\hline Cr (hexa) & $\mathrm{mg} / \mathrm{L}$ & $\max$. & 0.060 & 0.059 & 0.821 \\
\hline $\mathrm{Hg}$ & $\mathrm{mg} / \mathrm{L}$ & $\max$. & 0.178 & 0.259 & 0.460 \\
\hline $\mathrm{Ni}$ & $\mathrm{mg} / \mathrm{L}$ & $\max$. & 0.016 & 0.012 & 0.037 \\
\hline $\mathrm{Zn}$ & $\mathrm{mg} / \mathrm{L}$ & $\max$. & 0.050 & 0.06 & 0.061 \\
\hline \multicolumn{3}{|c|}{ Quality class } & 2 & 3 & 4 \\
\hline
\end{tabular}

Based on these parameters the gonadal index (GI - relation between gonadal weight and volume of the fish), the gonadal-somatic relationship (GSR - relation between gonadal weight and weight of the fish) and the condition factor $(\mathrm{K}-$ general measure of well-being) were calculated applying the equations suggested by Strange (1990), Wootton (1990), and Vazzoler (1981):

$$
\begin{aligned}
& \mathrm{GI}=\mathrm{Wo} / \mathrm{Lt}^{\mathrm{b}} \\
& \mathrm{GSR}=\mathrm{Wo} \times 100 / \mathrm{Wt} \\
& \mathrm{K}=\mathrm{Wt} / \mathrm{Lt}^{\mathrm{b}}
\end{aligned}
$$

Where: Wo = ovary weight; $\mathrm{Wt}=$ total weight; $\mathrm{Lt}=$ total length; and $\mathrm{b}=$ slope of the regression line of the relation $\log _{10} \mathrm{Wt}$ and $\log _{10} \mathrm{Lt}$.

\section{Data analysis}

In the first step, data per sampling site were separated according to length classes of the fish. The ANOVA was applied to test if the mean oocyte diameter, gonadal index, gonadal-somatic relationship, and condition factor were length-dependent. Out of 12 comparisons per length class, 10 showed no significant differences $(p>0.05)$, and 2 cases $(\mathrm{p}=0.0427$ and $\mathrm{p}=0.0475)$ were considered borderline (Table 2). Based on these results, the data of all fish per sampling site were grouped to increase the statistical power of subsequent tests.
The mean value for each parameter per site was calculated. In the second step, the mean of each parameter from the polluted sites at Parobé and São Leopoldo were compared with the means of the Monjolo reference site by applying Student-t-test ( $\mathrm{p}=0.05$ significance level; Statistix Version 1.0).

\section{RESULTS}

At all research sites, A. fasciatus was a common species at $15 \%$ to $22 \%$ of total fish abundance. Of 328 captured individuals with a total length exceeding $10 \mathrm{~cm}, 81$ were mature stage 3 females and included in the investigation. Thirty-three specimens were captured at Monjolo (reference site), 19 in Parobé and 29 in São Leopoldo. The greatest mean oocyte diameter was registered in Monjolo, the lowest in São Leopoldo. Oocytes collected in Parobé were of intermediate sizes.

The mean gonadal index and gonadal-somatic relationship displayed the same pattern, decreasing from the reference site to the most polluted site. The mean, minimum, and maximum values for all parameters are given in Table 3. The site-to-site comparisons of the parameters showed that all differences between Monjolo and São Leopoldo were significant (Table 4). 
TABLE 2

ANOVA of mean values $(\bar{X})$ of oocyte diameter (diam), gonadal index (GI), gonado-somatic relationship (GSR), and condition factor $(K)$ per length class and study site.

\begin{tabular}{|c|c|c|c|c|c|c|c|c|c|c|c|c|}
\hline \multirow{2}{*}{$\begin{array}{l}\text { Length } \\
\text { class } \\
(\mathrm{cm})\end{array}$} & \multicolumn{4}{|c|}{ Monjolo (reference) } & \multicolumn{4}{|c|}{ Parobé } & \multicolumn{4}{|c|}{ São Leopoldo } \\
\hline & $\begin{array}{c}\bar{X} \\
\operatorname{diam} \\
(\mathbf{m m})\end{array}$ & $\begin{array}{c}\bar{X} \\
\mathbf{G I}\end{array}$ & $\begin{array}{c}\bar{X} \\
\text { GSR }\end{array}$ & $\begin{array}{c}\bar{X} \\
\mathbf{K}\end{array}$ & $\begin{array}{c}\bar{X} \\
\operatorname{diam} \\
(\mathbf{m m})\end{array}$ & $\begin{array}{r}\bar{X} \\
\mathbf{G I}\end{array}$ & $\begin{array}{c}\bar{X} \\
\text { GSR }\end{array}$ & $\begin{array}{c}\bar{X} \\
\mathbf{K}\end{array}$ & $\begin{array}{r}\bar{X} \\
\operatorname{diam} \\
(\mathbf{m m})\end{array}$ & $\begin{array}{r}\bar{X} \\
\text { GI }\end{array}$ & $\begin{array}{r}\bar{X} \\
\text { GSR }\end{array}$ & $\underset{\mathbf{K}}{\bar{X}}$ \\
\hline $10-10.9$ & nd & nd & nd & nd & 0.7809 & 1.1569 & 16.4560 & 0.5873 & 0.7672 & 0.4671 & 7.2837 & 0.5945 \\
\hline $11-11.9$ & nd & nd & nd & nd & 0.8215 & 0.5699 & 7.5594 & 0.6969 & 0.7432 & 0.5788 & 9.1912 & 0.5681 \\
\hline $12-12.9$ & 0.8836 & 0.6260 & 11.0620 & 0.5033 & 0.7877 & 0.4068 & 8.2668 & 0.4515 & 0.7612 & 0.4934 & 8.2263 & 0.5419 \\
\hline $13-13.9$ & 0.8301 & 0.5677 & 10.5080 & 0.4782 & 0.7980 & 0.3669 & 5.9791 & 0.5819 & 0.7780 & 0.6102 & 9.9488 & 0.5461 \\
\hline $14-14.9$ & 0.8091 & 0.7732 & 13.2130 & 0.5046 & 0.8398 & 0.8345 & 12.4770 & 0.5790 & 0.7564 & 0.5985 & 9.7231 & 0.5468 \\
\hline $15-15.9$ & 0.8520 & 0.7277 & 13.4360 & 0.4849 & 0.8203 & 0.6626 & 10.4770 & 0.5502 & 0.7638 & 0.4208 & 6.7618 & 0.5792 \\
\hline $16-16.9$ & 0.8406 & 0.7145 & 12.5870 & 0.4889 & 0.7877 & 0.3787 & 8.0059 & 0.4680 & 0.7624 & 0.8270 & 11.9290 & 0.6106 \\
\hline $\begin{array}{c}\text { ANOVA } \\
\text { (p) }\end{array}$ & $0.0427 *$ & $0.2418 * *$ & $0.3221 * *$ & $0.6896^{* *}$ & $0.4565^{* *}$ & $0.0475^{*}$ & $0.0913 * *$ & $0.1353^{* *}$ & $0.9452 * *$ & $0.6985^{* *}$ & $0.6892 * *$ & $0.8336^{* *}$ \\
\hline
\end{tabular}

* Significant difference, but considered border line value (near $\mathrm{p}=0.05$ ).

$* *$ Not significant $(\mathrm{p}>0.05)$.

nd $=$ no data (no fish captured).

\section{TABLE 3}

Minimum, maximum, and mean values $(\bar{X})$, standard deviation (sd) and number (n) per site and parameter (diam = oocyte diameter, $\mathrm{K}=$ condition factor, $\mathrm{GI}=$ gonadal index, GSR = gonado-somatic relationship).

\begin{tabular}{|c|c|c|c|c|c|c|c|c|c|c|c|c|}
\hline & \multicolumn{4}{|c}{ Monjolo } & \multicolumn{4}{c|}{ Parobé } & \multicolumn{4}{c|}{ São Leopoldo } \\
\hline & min.-max. & $\bar{X}$ & sd & $\mathbf{n}$ & min.-max. & $\bar{X}$ & sd & $\mathbf{n}$ & min.-max. & $\bar{X}$ & sd & $\mathbf{n}$ \\
\hline $\begin{array}{c}\text { Diam } \\
(\mathrm{mm})\end{array}$ & $0.2740-1.0960$ & 0.8326 & 0.1492 & 660 & $0.2740-1.2330$ & 0.8185 & 0.1736 & 400 & $0.2740-1.2330$ & 0.7612 & 0.2076 & 600 \\
\hline K & $0.4054-0.5747$ & 0.4891 & 0.0400 & 33 & $0.3867-0.6969$ & 0.5618 & 0.0758 & 19 & $0.4478-0.6440$ & 0.5545 & 0.0531 & 29 \\
\hline GI & $0.2508-1.0731$ & 0.6821 & 0.2098 & 33 & $0.2296-1.2673$ & 0.6324 & 0.3017 & 19 & $0.2790-1.0901$ & 0.5611 & 0.2046 & 29 \\
\hline GSR & $4.8095-19.4240$ & 12.2240 & 3.3895 & 33 & $3.2567-16.4560$ & 9.9381 & 4.0409 & 19 & $4.5033-16.8380$ & 9.0307 & 2.8957 & 29 \\
\hline
\end{tabular}

Only the comparison of oocyte diameter and GI between Monjolo and Parobé indicated no significant differences.

The mean condition factor $(\mathrm{K})$ displayed an inverse relationship. It increased from up to downriver. The differences found between the condition factors at Monjolo and the other sites were significant.

\section{DISCUSSION}

Reproduction-related parameters of A. fasciatus, such as gonadal index and gonadal-somatic relationship, decreased with the increasing pollution gradient of the Rio dos Sinos. Fish from the most contaminated site at São Leopoldo displayed significantly smaller oocyte diameter, lower gonadal 
index, and gonadal-somatic relationship. Water contamination, particularly from heavy metals, is considered to be the major cause of the phenomenon.

In his review of the subject, Von Westernhagen (1988) mentions numerous studies which show that heavy metals may reduce oocytes volume, as indicated by reduction of the oocyte diameter. Exposure of fish to low levels (micrograms per liter) of zinc, cadmium, copper, mercury, or pesticides may lead to an $80 \%$ reduction of egg production. Egg deposition of fathead minnows (Pimephales promelas) at copper concentrations of $18-32 \mu \mathrm{g} /$ L was completely interrupted (Mount \& Stephan 1969); low concentrations of zinc $(180 \mu \mathrm{g} / \mathrm{L})$ reduced the number of eggs by some $83 \%$ (Brungs, 1969). A progressive decrease in spawning activity and egg numbers in this species was reported by Eaton (1973) after exposure to 3.7-31 $\mu \mathrm{g} / \mathrm{L}$ copper and $0.6-60 \mu \mathrm{g} / \mathrm{L}$ cadmium. Zinc concentrations of $130-200 \mu \mathrm{g} / \mathrm{L}$ caused a $21 \%$ reduction in eggs spawned in minnows (Phoxinus phoxinus; Bengtsson, 1974). The life-bearing guppy Poecilia reticulata reduced the clutch size of the young about $50 \%$ when exposed to $170-360 \mu \mathrm{g}$ zinc/L (Uviovo \& Beatty, 1979). According to Dave \& Xiu (1991) low concentrations of copper $(0.25 \mu \mathrm{g} / \mathrm{L})$, lead (30 $\mu \mathrm{g} / \mathrm{L})$, mercury, $(0.2 \mu \mathrm{g} / \mathrm{L})$ and nickel $(80 \mu \mathrm{g} / \mathrm{L})$ can interfere in hatching and survival of the zebra fish (Brachydanio rerio). Maximum values of cadmium, lead, copper, and mercury reached critical levels in São Leopoldo and to a lesser degree in Parobé (Table 1, FEPAM, 1999). Only nickel and zinc concentrations are lower at all sites.

Synergistic effects cannot be excluded. Low $\mathrm{pH}$ values such as those measured at São Leopoldo, might enhance the toxic effects on reproductive systems of fish (von Westernhagen, 1988). Bioaccumulation leads to elevated heavy metal concentration in fish. In an unpublished analysis of heavy metals in Astyanax (probably A. fasciatus) upstream from São Leopoldo, the Department of Environmental Protection of Novo Hamburgo found high concentrations of copper $(3.26 \mathrm{mg} / \mathrm{kg})$, lead $(2.71 \mathrm{mg} / \mathrm{kg})$, nickel $(8.96$ $\mathrm{mg} / \mathrm{kg})$ and zinc $(51.26 \mathrm{mg} / \mathrm{kg})$. These concentrations exceed recommended maximum values up to a factor of 100 (DMAE, 1983).

The high organic load and hydrological characteristics of Rio dos Sinos in the lower reaches cause low concentrations of dissolved oxygen in the area of São Leopoldo. Mean values of between 2 and 3 $\mathrm{mg} / \mathrm{L}$ can drop to $0.2 \mathrm{mg} / \mathrm{L}$ (Table 1; FEPAM, 1999). Mitchell \& Bo-Collings (1997), suggesting that decline in oogenesis and vitellogenesis may be associated with low concentrations of dissolved oxygen, which might interfere in yolk accumulation, and consequently, alter oocyte size.

TABLE 4

Results of student-test comparison between the mean $(\bar{X})$ of parameters of the reference site with the mean of the parameters of polluted sites $(\mathrm{diam}=$ oocyte diameter, $\mathrm{K}=$ condition factor, $\mathrm{GI}=$ gonadal index, GSR = gonado-somatic relationship).

\begin{tabular}{|l|c|c|c|c|}
\hline Parameters & Site comparison & $\bar{X}$ reference site & $\bar{X}$ polluted site & p \\
\hline Diam $(\mathrm{mm})$ & Monjolo $x$ Parobé & 0.8326 & 0.8185 & $0.1740^{* *}$ \\
\hline K & Monjolo x Parobé & 0.4891 & 0.5618 & $0.0007^{*}$ \\
\hline GI & Monjolo x Parobé & 0.6821 & 0.6324 & $0.5305^{* *}$ \\
\hline GSR & Monjolo x Parobé & 12.2240 & 9.9381 & $0.0338^{*}$ \\
\hline Diam $(\mathrm{mm})$ & Monjolo x São Leopoldo & 0.8326 & 0.7612 & $0.0000^{*}$ \\
\hline K & Monjolo $\times$ São Leopoldo & 0.4891 & 0.5545 & $0.0000^{*}$ \\
\hline GI & Monjolo x São Leopoldo & 0.6821 & 0.5611 & $0.0241^{*}$ \\
\hline GSR & Monjolo x São Leopoldo & 12.2240 & 9.0307 & $0.0002^{*}$ \\
\hline
\end{tabular}

* Significant difference $(\mathrm{p}<0.05)$;

** Nonsignificant $(\mathrm{p}>0.05)$. 
Decreasing reproductive parameters were accompanied by increasing condition factors in A. fasciatus. Adams et al. (1996), working on redbreast sunfish (Lepomis auritus), found an increase of condition factors in sites contaminated by pulp and paper effluents and a decrease of the visceral-somatic index, which reflects lipid stores in viscera. Their explanation for these effects coincides with that of McMaster et al. (1991) who postulate that an increased condition factor and a decreased energetic commitment to visceral lipid storage and reproduction could be explained by a disruption in metabolic capability and altered energy allocation. Since this study did not measure the visceral somatic index, it is not known if $A$. fasciatus from contaminated Rio dos Sinos sites follow exactly the same pattern. But the decreased gonadal indices and gonadal-somatic relationships showed clearly that energy was not allocated to the gonads. Altered energy allocation may not reflect environmental stress but other environmental factors, such as habitat and food availability, which usually increase from upstream to downstream.

Comparison of our data with the studies cited strongly suggests that water contamination of Rio dos Sinos interferes with the reproductive system of $A$. fasciatus. Since this species is considered to be resistant to water pollution, interference of pollutants with other more sensitive species is very likely. The long-term decline in species abundance and an unknown amount of species richness may be attributed to the high impact from pollution.

The results of this study recommend the use of $A$. fasciatus in biomonitoring studies. It is a common, easily catchable species with a reproductive system sufficiently sensitive to contaminants.

\section{REFERENCES}

ADAMS, S. M., HAM, K. D., GREELEY, M. S., LEHEW, R. F., HINTON, D. E. \& SAYLOR, C. F., 1996, Downstream gradients in bioindicator response: point source contaminant effects on fish health. Can. J. Fish. Aquat. Sci., 53: 2177-2187.

Agostinho, C. A., MOLINARI, S. L., AGOSTINHO, A. A. \& VERANI, J. R., 1984, Ciclo reprodutivo e primeira maturação sexual de fêmeas de lambari, Astyanax bimaculatus do rio Ivaí, Estado do Paraná. Rev. Brasil. Biol., 44(1): 31-36.

ARAÚJO, F. G., 1998, Adaptação do índice de integridade biótica usando a comunidade de peixes para o Rio Paraíba do Sul. Rev. Brasil. Biol., 58(4): 547-558.
BENGTSSON, B. E., 1974, The effects of zinc on mortality and reproduction of the minnow, Phoxinus phoxinus. Arch. Environ. Contam. Toxicol., 2: 342-355.

BRUNGS, W. A., 1969, Chronic toxicity of zinc to fathead minnow, Pimephales promelas Rafinesque. Trans. Am. Fish. Soc., 98: 272-279.

DAVE, G. \& XIU, R., 1991, Toxicity of mercury, copper, nickel, lead, and cobalt to embryos and larvae of zebrafish, Brachydanio rerio. Arch. Environ. Contam. Toxicol, 21: 126-134.

DMAE - Departamento Municipal de Água e Esgoto, 1983, Inventário e classificação da íctiofauna do Rio Guaíba e pesquisa de metais e substâncias tóxicas, 85p.

EATON, J. G., 1973, Chronic toxicity of copper, cadmium and zinc mixture to flathead minnow (Pimephales promelas Rafinesque). Water Res., 7: 1723-1736.

FEPAM - FUNDAÇÃO ESTADUAL DE PROTEÇÃO AMBIENTAL, 1999, Qualidade das águas do Rio dos Sinos. Departamento de qualidade ambiental. Divisão de planejamento e diagnóstico. Monitoramento da qualidade da água, 49p.

FIUMAN, L. A., 1993, Water quality and the early life stages of fishes. American Fisheries Society Symposium 14, $172 \mathrm{p}$.

GHETTI, P. F. \& RAVERA, O., 1994, European perspective on biological monitoring, 31-48. In: S. Loeb \& A. Spacie (eds.), Biological monitoring of aquatic systems. Lewis Publishers, Boca Raton, 381p.

HERRICK, E. E., 1991, General principles of toxicology, pp. 7-27. In: ILEC, Toxic substances management in lakes and reservoirs. Guidelines of Lake Management 4.

KARR, J. R., 1981, Assessment of biotic integrity using fish comunities. Fisheries, 6: 21-27.

LANNO, R. P. \& DIXON, D. G., 1994, Chronic toxicity of waterborn thiocyanate to the fathead minnow (Pimephales promelas): a partial life cicle study. Environ. Toxicol. Chem., 13(9): 1423-1432.

LANDRES, P. B., VERNER, J. \& THOMAS, J. W., 1988, Ecological use of vertebrate indicator species: A critique. Conserv. Biol., 2(4): 316-328.

LEATHERLAND, J. F., 1993, Field observations on reproductive and developmental dysfunctions in introduced and native salmonids from the Great Lakes. J. Great Lakes Res., 19(4): 737-751.

MCMASTER, M. E., VAN DER KRAAK, G. J., PORTT, C. B., MUNKITRICK, K. R., SIBLEY, P. K., SMITH, I. R. \& DIXON, D. G., 1991, Changes in hepatic mixed function oxygenase activity, plasma steroid levels and age at maturity of a white sucker (Catostomus comersoni) population exposed to bleached kraft pulp mill effluent. Aquat. Toxicol., 21: 199-218.

MENNI, R. C.; GOMEZ, S. E. \& LOPEZ-ARMENGOL, F., 1996, Subtle relationships: freswater fishes and water chemistry in southern South América. Hydrologia, 328(3): 173-197. 
MITCHELL, A. J. \& BO-COLLINGS, C., 1997, Some problems associated with the use of well water in hatching eggs and holding fish. Aquacult. Mag., 23(2): 91-94.

MOUNT, D. I. \& STEPHAN, C. E., 1969, Chronic toxicity of copper to fathead minnow (Pimephales promelas) in soft water. J. Fish. Res. Board Can., 26: 2449-2457.

NATIONAL RESERACH COUNCIL, 1986, Ecological knowledge and enviromental problem-solving. National Academy Press, Washington, DC, 131.

NOMURA, H., 1975, Fecundidade, maturação sexual e índice gônado-somático de lambaris do gênero Astyanax, relacionadas com fatores ambientais. Rev. Brasil. Biol., 35(4): 776-798.

NOMURA, H., 1984, Dicionário de peixes do Brasil. Editerra, Brasília, 482p.

STRANGE, R. J., 1990, Field examination of fishes. In: C. B. Schreck \& P. Moyle (eds.), Methods for fish biology. American Fisheries Society, Bethesda, Maryland, 681p.

UVIOVO, E. J. \& BEATTY, D. D., 1979, Effects of chronic exposure to zinc on reproduction in the guppy (Poecilia reticulata). Bull. Environ. Contam. Toxicol., 23: 650-657.
VAZZOLER, A. E. A. M., 1981, Manual de métodos para estudos biológicos de populações de peixes: reprodução e crescimento. Programa Nacional de Zoologia/CNPq, Brasília, 106p.

VAZZOLER, A. E. A. M., 1992, Síntese de conhecimentos sobre o comportamento reprodutivo dos Characiformes da América do Sul. Rev. Brasil. Biol., 52(4): 627-640.

VAZZOLER, A. E. A. M., 1996, Biologia da reprodução de peixes teleósteos: teoria e prática. EDUEM, Maringá, $169 \mathrm{p}$.

VON WESTERNHAGEN, H., 1988, Sublethal effects of pollutants on fish eggs and larvae. pp. 253-346. In: W. S. Hoar \& D. J. Randall (eds.), Fish Physiology vol. XIA The physiology of developing fish. Academic Press, San Diego, 546p.

WOOTTON, R. J., 1990, Ecology of teleost fishes. Fish and Fisheries Series 1. Chapman and Hall, New York, 404p. 